\title{
PERANAN GURU DALAM PEMBINAAN AKHLAK MULIA PESERTA DIDIK (STUDI KASUS DI MIS DARUL ULUM, MADIN SULAMUL ULUM DAN TPA AZ-ZAHRA DESA PAPUYUAN)
}

Oleh:

\author{
Miftahul Jannah \\ Dosen, Sekolah Tinggi Ilmu Al-Qur'an (STIQ) Amuntai, \\ Kalimantan Selatan
}

\begin{abstract}
Abstrak
Guru agama bertingkah laku dengan baik, maka siswanya akan mencontoh prilaku tersebut. Akan tetapi sebaliknya, jika guru agama tidak memberikan contoh yang baik, maka siswanya juga akan meniru kelakuan tersebut. Bayangan tidak akan terlihat lurus apabila tongkat itu berdiri bengkok yang artinya bagaimana murid akan menjadi baik, apabila gurunya berkelakuan tidak baik. Pengaruh negatif dari sekitar akan memperburuk pemahaman siswa tentang akhlak, yang lingkungan semula sudah diajarkan dan dapat dipahami oleh siswa bisa saja rusak atau berubah akibat pergaulan buruk yang diterimanya. Walaupun orang tuanyalah yang berperan dalam pembinaan akhlak anak-anak mereka. Akan tetapi keberadaan guru dan peran guru cenderung dapat memberikan motifasi dalam menanamkan pemahaman Akhlak pada diri anak, sehingga pemahaman tersebut bukan hanya pemahaman saja, tetapi dapat juga di amalkan. ${ }^{1}$ Tujuan dari penelitian ini adalah: Mendeskripsikan dan menganalisis (1)Peran guru dalam membina akhlak mulia peserta didik, (2) faktor-faktor apa saja yang menjadi pendukung dan penghambat upaya guru dalam membina akhlak mulia peserta di MIS Darul Ulum dan TPA Az-Zahra Desa Papuyuan, (3) media pembinaan siswa untuk membina akhlak mulia peserta didik di MIS Darul Ulum dan
\end{abstract}

${ }^{1}$ H. Zuhairini, dkk, Methodik Khusus Pendidikan Agama, (Malang: Biro Ilmiah Fakultas Tarbiyah IAIN Sunan Ampel, 1981), h. 35.

Al-Madrasah: Jurnal Ilmiah Pendidikan Madrasah Ibtidaiyah

Vol. 3, No. 2, Januari-Juni 2019 
Miftahul Jannah: Peranan Guru dalam Pembinaan Akhlak Mulia Peserta Didik (Studi Kasus di MIS Darul Ulum, Madin Sulamul Ulum dan TPA Az-Zahra Desa Papuyuan)

TPA Az-Zahra Desa Papuyuan. Penelitian ini menggunakan pendekatan kualitatif dengan jenis penelitian studi kasus (study case). Teknik pengumpulan data yang digunakan adalah wawancara, observasi, dan dokumentasi. Hasil Penelitian menunjukan (1) Peran guru Madrasah Ibtidaiyah Swasta Darul Ulum dan Taman Pendidikan Al Quran Az-Zahra sangat berperan aktif dalam pembinaan akhlak siswa baik dalam kegiatan keagamaan maupun non keagamaan. Kegiatan pembinaan akhlak yang dilakukan guru seperti mengajari bagaimana caranya hormat kepada guru, tata cara hidup berdisiplin yang baik, ramah pada lingkungan, shalat wajib dan sunnah berjamaah, tahfiz, habsyi, dan lain sebagainya. (2) faktor pendukung seperti keluarga, lingkungan masyarakat, lingkungan tempat tinggal, dan juga tata terbit sekolah.dan penghambat keterbatasan waktu, keterbatan pengawasan, perilaku siswa, pergaulan, teknologi, kesadaran diri, dan sarana prasarana yang tidak memadai dalam membina akhlak mulia peserta didik di MIS Darul Ulum dan TPA Az-Zahra Desa Papuyuan. (3) Media pembinaan siswa untuk membina akhlak mulia peserta didik di MIS Darul Ulum dan TPA Az-Zahra Desa Papuyuan ialah guru sebagai tenaga pendidik, orang tua, dan lingkungan sekolah.

Kata Kunci: Peranan Guru, pembinaan akhlak mulia.

\section{A. Pendahuluan}

Pendidikan adalah merupakan dimensi krusial dalam kehidupan manusia, sebab pendidikan merupakan wahana pengembangan keadaan manusia dari yang tidak baik menjadi baik, dari yang sederhana menjadi modern, dari yang rendah menjadi lebih tinggi. Senada dengan hal tersebut Islam juga telah mencontohkan bahwa pendidikan adalah hal penting yang harus ada dalam aspek kehidupan, hal tersebut dapat dilihat pada perintah Allah pertama kali kepada Nabi Muhammad saw melalui wahyu pertama, dengan turunnya ayat ini Allah swt. melantik Muhammad sebagai Nabi-Nya yang terakhir. Salah satu komponen yang sangat penting dalam pendidikan adalah guru. Dalam UndangUndang Nomor 14 Tahun 2005 dikatakan "Guru adalah pendidik profesional dengan tugas utama mendidik, mengajar, membimbing, mengarahkan, melatih, menilai dan mengevaluasi peserta didik pada pendidikan anak usia dini jalur pendidikan formal, pendidikan dasar, pendidikan menengah". ${ }^{2}$

${ }^{2} \mathrm{HM}$ Djumransjah dan Abdul Malik Karim Amrullah. Pendidikan Islam. (Malang: UIN Malang Press, 2007), h. 42. 
Miftahul Jannah: Peranan Guru dalam Pembinaan Akhlak Mulia Peserta Didik (Studi Kasus di MIS Darul Ulum, Madin Sulamul Ulum dan TPA Az-Zahra Desa Papuyuan)

Zakiah Daradjat menjelaskan bahwa Guru adalah pendidik profesional, karenanya secara impilisit ia telah merelakan dirinya menerima dan memikul sebagian tanggung jawab pendidikan yang terpikul di pundak orang tua. Guruguru yang menjalankan tugas mendidik sudah tentu harus sanggup menjadikan dirinya sebagai sarana penyampaian cita-cita kepada peserta didik yang telah diamanatkan kepadanya. Itulah sebabnya guru sebagai subjek pendidikan harus memenuhi syarat-syarat yang dapat dipertanggung jawabkan dalam pendidikan baik dari segi jasmaniah maupun rohaniyah.Guru yang memiliki peran sangat besar dalam mendidik, mengajar, membimbing, mengarahkan, melatih, menilai, dan mengevaluasi harus mempunyai kompetensi.

Kompetensi meliputi aspek pedagogik, kepribadian, profesionalisme, dan sosial. Hal ini adalah sebuah keharusan bagi seorang guru sebab guru adalah manusia pilihan, yang tidak sembarang manusia sanggup melaksanakannya. Seorang guru juga harus membangun paradigma berpikir bahwa pendidikan adalah proses pencerdasan secara utuh. Salah satu ajaran dasar Nabi saw adalah intelektualisasi total atau dalam bahasa sederhana adalah pendidikan yang menjangkau ranah kognitif, afektif dan psikomotorik.

Guru adalah figur manusia yang menempati posisi dan memegang peranan penting dalam pendidikan. Ketika semua orang mempersoalkan masalah dunia pendidikan, figur guru mesti dilibatkan dalam agenda pembicaraan terutama yang menyangkut persoalan pendidikan formal di sekolah. Hal itu tidak dapat disangkal, karena lembaga pendidikan formal adalah dunia kehidupan guru. Guru sebagai figur sentral dalam dunia pendidikan, khususnya dalam proses belajar mengajar. Sehubungan dengan ini, setiap guru sangat diharapkan memiliki karakteristik (ciri khas) kepribadian yang ideal sesuai dengan persyaratan yang bersifat psikologis-pedagogis. ${ }^{3}$

Guru memiliki peran ganda, yakni sebagai pengajar sekaligus sebagai pendidik. Dalam rangka mengembangkan peran gandanya, maka Ahmad Ke-2, h. 110 .

${ }^{3}$ Jalaludin, Teologi Pendidikan, (Jakarta: Raja Grapindo Persada, 2002), cet. 
Miftahul Jannah: Peranan Guru dalam Pembinaan Akhlak Mulia Peserta Didik (Studi Kasus di MIS Darul Ulum, Madin Sulamul Ulum dan TPA Az-Zahra Desa Papuyuan)

Rohani dan A.Abu Ahmadi mengutip pendapatnya Zakiah Daradjat yang menyarankan agar guru memiliki persyaratan kepribadian sebagai guru yaitu: Suka bekerja keras, demokratis, penyayang, menghargai kepribadian peserta didik, sabar, memiliki pengetahuan, ketrampilan dan pengalaman yang bermacam-macam, perawakan menyenangkan dan berkelakuan baik, adil dan tidak memihak, toleransi, mantap dan stabil, ada perhatian terhadap persoalan peserta didik, lincah, mampu memuji, perbuatan baik dan menghargai peserta didik, cukup dalam pengajaran, mampu memimpin secara baik. ${ }^{4}$

Untuk tercapainya tujuan tersebut, maka guru memegang peranan penting. Oleh sebab itu guru di sekolah tidak hanya sekedar mentransfer sejumlah ilmu pengetahuan kepada murid-muridnya, tetapi lebih dari itu terutama dalam membina sikap dan keterampilan mereka. Untuk membina sikap murid di sekolah, dari sekian banyak guru bidang studi, guru bidang studi agamalah yang sangat menentukan, sebab pendidikan agama sangat menentukan dalam hal pembinaan sikap siswa karena bidang studi agama banyak membahas tentang pembinaan sikap, yaitu mengenai aqidah dan akhlakul karimah. Pendidikan karakter merupakan solusi yang tepat untuk keberlangsungan pendidikan di masa yang akan datang. ${ }^{5}$

Tugas guru tidak terbatas pada memberikan informasi kepada murid namun tugas guru lebih komprehensif dari itu. Selain mengajar dan membekali murid dengan pengetahuan, guru juga harus menyiapkan mereka agar mandiri dan memberdayakan bakat murid di berbagai bidang, mendisiplinkan moral mereka, membimbing hasrat dan menanamkan kebajikan dalam jiwa mereka. Guru harus menunjukkan semangat persaudaraan kepada murid serta membimbing mereka pada jalan kebenaran agar mereka tidak melakukan perbuatan yang menyimpang dari ajaran agama. Faktor guru sangat mendukung

${ }^{4}$ Muhibbin Syah, Psikologi pendidikan suatu pendekatan baru, (Bandung:Remaja Rosdakarya, 1996), h.221.

${ }^{5}$ Agus Setiawan, Prinsip Pendidikan Karakter dalam Islam (Studi Komparasi Pemikiran al-Ghazali dan Burhanuddin al-Zarnuji), Dinamika Ilmu, 14 (1), 2014, hal. 10 
Miftahul Jannah: Peranan Guru dalam Pembinaan Akhlak Mulia Peserta Didik (Studi Kasus di MIS Darul Ulum, Madin Sulamul Ulum dan TPA Az-Zahra Desa Papuyuan)

dalam mendidik prilaku siswa. Hal ini disebabkan karena guru merupakan suri tauladan bagi siswanya. Jika seorang guru agama bertingkah laku dengan baik, maka siswanya akan mencontoh prilaku tersebut. Akan tetapi sebaliknya, jika guru agama tidak memberikan contoh yang baik, maka siswanya juga akan meniru kelakuan tersebut. Dalam hal ini Zuhairini mengutip pendapat dari prof. Athiyah Al-abrossyi yang menyatakan bahwa :"Hubungan antara murid dengan guru seperti halnya bayangan dengan tongkatnya. Bayangan tidak akan terlihat lurus apabila tongkat itu berdiri bengkokyang artinya bagaimana murid akan menjadi baik, apabila gurunya berkelakuan tidak baik. Dalam pepatah bahasa Indonesia dikatakan bahwa guru kencing berdiri, murid kencing berlari yang artinya murid akan mencontoh apa yang telah dilakukan oleh gurunya". ${ }^{6}$

Pengaruh negatif dari sekitar bisa jadi akan memperburuk pemahaman siswa tentang akhlak, yang lingkungan semula sudah diajarkan dan dapat dipahami oleh siswa bisa saja rusak atau berubah akibat pergaulan buruk yang diterimanya. Walaupun orang tuanyalah yang berperan dalam pembinaan akhlak anak-anak mereka. Akan tetapi keberadaan guru dan peran guru cenderung dapat memberikan motifasi dalam menanamkan pemahaman Akhlak pada diri anak, sehingga pemahaman tersebut bukan hanya pemahaman saja, tetapi dapat juga di amalkan. Oleh karena itu, peranan seorang guru, khususnya guru agama Islam diupayakan untuk dapat membentuk siswa agar memiliki kepribadian muslim serta berakhlak mulia. ${ }^{7}$

Melihat latar belakang masalah di atas, maka penulis disini berpendapat bahwa seorang guru bukan hanya seorang pengajar saja tetapi seorang guru sebagai pendidik yang dapat mengarahkan siswa-siswinya. Oleh karena itu peranan guru sangat diperlukan dalam membentuk kepribadian mpara siswa yang berakhlak mulia. Hal ini mendorong penulis untuk melihat lebih dalam bagaimana peran

\footnotetext{
${ }^{6}$ Ahmad Rohani dan A.Abu Ahmadi, Pengelolaan Pengajaran, ( Jakarta: Rineka Cipta, 1996), h.110.

${ }^{7}$ H. Zuhairini, dkk, Methodik Khusus Pendidikan Agama, (Malang: Biro Ilmiah Fakultas Tarbiyah IAIN Sunan Ampel, 1981), h. 35.
}

\section{Al-Madrasah: Jurnal Ilmiah Pendidikan Madrasah Ibtidaiyah}

Vol. 3, No. 2, Januari-Juni 2019 
Miftahul Jannah: Peranan Guru dalam Pembinaan Akhlak Mulia Peserta Didik (Studi Kasus di MIS Darul Ulum, Madin Sulamul Ulum dan TPA Az-Zahra Desa Papuyuan)

guru dalam pembinaan akhlak siswa dengan suatu penelitian yang berjudul "Peranan Guru Dalam Pembinaan Akhlak Mulia Peserta Didik (Studi Kasus Di MIS Darul Ulum dan TPA Az-Zahra Desa Papuyuan).

\section{B. Metode Penelitian}

\section{Pendekatan dan Jenis Penelitian}

Pendekatan dan Jenis penelitian yang penulis lakukan adalah penelitian kualitatif dengan jenis penelitian studi kasus. Menurut Kirk dan Miller dalam Lexy J.Moleong mendefinisikan bahwa penelitian kualitatif adalah tradisi tertentu dalam ilmu pengetahuan sosial yang secara fundamental bergantung pada pengamatan manusia dalam kawasannya sendiri dan hubungan dengan orang-orang tersebut dalam bahasanya dan dalam peristilahannya. ${ }^{8}$

Adapun jenis penelitian menggunakan studi kasus yang di dasarkan atas keunikan latar penelitian. Studi kasus ialah suatu kajian yang rinci dengan satu latar, atau subjek tunggal, atau satu tempat penyimpanan dokument atau suatu peristiwa tertentu. ${ }^{9}$ Suatu kasus itu bisa berupa individu, keluarga, pusat kesehatan masyarakat atau suatu organisasi. Kasus yang diteliti dalam penelitian ini terfokus pada Peranan Guru dalam Pembinaan Akhlak Mulia Peserta Didik

\section{Kehadiran Peneliti}

Peneliti dalam penelitian ini sebagai instrument pengumpul data. Selain itu instrument pendukung penelitian ini adalah pedoman wawancara, pedoman observasi dan dokumentasi. Kemudian mengenai status peneliti adalah sebagai pengamat penuh serta diketahui subjek atau informan. Disamping itu kehadiran peneliti diketahui statusnya sebagai peneliti oleh kepala sekolah MIS Darul Ulum Desa Papuyuan dan TPA Az-Zahra Desa Papuyuan.

${ }^{8}$ Lexy. J. Moleong. "Metode Penelitian Kualitatif”, (Bandung: Remaja Rosda Karya, 2002), h. 3.

${ }^{9}$ Robert C. Bogdan dan Sari Nop Biklen, Qualitative Research in Education an Introduction to Theory and Method (London: Allyn and Bacon, 1998), h. 54. 
Miftahul Jannah: Peranan Guru dalam Pembinaan Akhlak Mulia Peserta Didik (Studi Kasus di MIS Darul Ulum, Madin Sulamul Ulum dan TPA Az-Zahra Desa Papuyuan)

\section{Latar Penelitian}

Penelitian ini berlokasi di MIS Darul Ulum Desa Papuyuan dan TPA AzZahra Desa Papuyuan yang beralamat di di desa Papuyunan Rt.07 Rw.04 desa Papuyuan Kecamatan Lampihong Kabupaten Balangan Kalimantan Selatan 70612. Adapun alasan peneliti memilih MIS Darul Ulum Desa Papuyuan dan TPA Az-Zahra Desa Papuyuan sebagai lokasi penelitian.

\section{Subjek dan Objek Penelitian}

\section{a. Subjek Penelitian}

Subjek dalam penelitian ini adalah civitas MIS Darul Ulum Desa Papuyuan dan TPA Az-Zahra Desa Papuyuan yang didalamnya terdiri atas kepala sekolah, kepala keisswaan, para guru dan siswa MIS Darul Ulum Desa Papuyuan dan TPA Az-Zahra Desa Papuyuan.

\section{b. Objek Penelitian}

Objek penelitian ini adalah peran yang dilakukan oleh guru dalam pembinaan akhalak, Faktor-faktor pendukung dan penghambat serta hasil Peranan Guru dalam Pembinaan Akhlak Mulia Peserta Didik MIS Darul Ulum Desa Papuyuan dan TPA Az-Zahra Desa Papuyuan.

\section{Data dan Sumber Data}

\section{a. Data}

1) Data Pokok

Data pokok yaitu data yang berkenaan dengan upaya-upaya yang dilakukan oleh guru dalam pembinaan akhalak, Faktor-faktor pendukung dan penghambat serta hasil Peranan Guru dalam Pembinaan Akhlak Mulia Peserta Didik

2) Data Penunjang

Data penunjang di sini yakni data tentang latar belakang lokasi penelitian yang meliputi sejarah singkat berdirinya MIS Darul Ulum Desa Papuyuan dan TPA Az-Zahra Desa Papuyuan, keadaan para siswa, pengajar dan karyawan, sarana dan prasarana, dan data 
Miftahul Jannah: Peranan Guru dalam Pembinaan Akhlak Mulia Peserta Didik (Studi Kasus di MIS Darul Ulum, Madin Sulamul Ulum dan TPA Az-Zahra Desa Papuyuan)

penunjang lainnya. Data sekunder biasanya telah tersusun dalam bentuk dokumen-dokumen yang sudah ada di MIS Darul Ulum Desa Papuyuan dan TPA Az-Zahra Desa Papuyuan.

\section{b. Sumber Data}

Adapun yang menjadi sumber data dalam penelitian ini adalah:

1) Informan, yaitu Kepala sekolah. Guru, bagian Kesiswaan, Pengurus Pengasuhan siswa dan para siswa.

2) Dokumen MIS Darul Ulum Desa Papuyuan dan TPA Az-Zahra Desa Papuyuan, yaitu seluruh data yang diperlukan dalam penelitian ini

\section{Tekhnik Pengumpulan Data}

Adapun teknik pengumpulan data yang digunakan penulis dalam penelitian ini adalah:

\section{a. Wawancara (Interview)}

Wawancara dalam suatu penelitian diantaranya bertujuan mengumpulkan keterangan tentang kehidupan manusia dalam suatu masyarakat. Memverifikasi, mengubah dan memperluas informasi yang diperoleh dari orang lain. ${ }^{10}$ Dalam melakukan wawancara ini peneliti melakukannya dengan dua tehnik, yaitu wawancara terstruktur dilakukan bila peneliti telah mengetahui tentang informasi yang ingin diperoleh; Wawancara tak terstruktur yang dilakukan hanya menggunakan pedoman wawancara dari garis-garis besar permasalahan yang akan ditanyakan. Kedua macam wawancara tersebut disesuaikan dengan dinamika yang ada pada saat peneliti berada dilapangan, ketika mewawancarai informan yang terdiri dari kepala sekolah, pengajar, para siswa.

\section{b. Pengamatan (observasi)}

Penelitian ini, peneliti menggunakan metode observasi partisipan. Pada observasi partisipan, peneliti ikut bergabung dengan sumber data di

${ }^{10}$ Burhan Bungin, Metodologi Penelitian Kualitatif (Jakarta: Raja Grafindo Persada, 2011), h.100.

\section{Al-Madrasah: Jurnal Ilmiah Pendidikan Madrasah Ibtidaiyah}

Vol. 3, No. 2, Januari-Juni 2019 
Miftahul Jannah: Peranan Guru dalam Pembinaan Akhlak Mulia Peserta Didik (Studi Kasus di MIS Darul Ulum, Madin Sulamul Ulum dan TPA Az-Zahra Desa Papuyuan)

lapangan. Dengan observasi pratisipan ini, maka data yang diperoleh akan lebih lengkap, tajam, dan sampai mengetahui pada tingkat makna dari setiap perilaku yang nampak.

\section{c. Dokumentasi}

Metode ini digunakan untuk mengumpulkan data yang tersedia dalam catatan dokumen. ${ }^{11}$ Dalam penelitian ini peneliti mengumpulkan data tertulis yang berupa arsip, atau bukti konkrit tertulis yang ada di MIS Darul Ulum Desa Papuyuan dan TPA Az-Zahra Desa Papuyuan dan yang mempunyai hubungan dengan masalah yang akan diteliti.

\section{Tekhnik Analisis Data}

Analisis data kualitatif adalah upaya yang dilakukan dengan jalan bekerja dengan data, mengorganisasikan data, memilah-milahnya menjadi satuan yang dapat dikelola, mensintesiskannya, mencari dan menemukan pola, menemukan apa yang penting dan apa yang dipelajari, dan memutuskan apa yang dapat diceritakan kepada orang lain. ${ }^{12}$

Peneliti melakukan analisis data melalui dua tahap yaitu: tahap pertama dilakukan selama berada dilapangan, tahap kedua dilakukan sesudah data terkumpul dan dalam menganalisis data ini peneliti menggunakan tehnik analisis data Miles dan Huberman, yang dilakukan melalui tiga langkah:

\section{a. Reduksi data}

Proses pemilihan, pemusatan perhatian, pengabstraksian dan pentransformasian data kasar dari lapangan. Fungsinya untuk menajamkan, menggolongkan, mengarahkan, membuang yang tidak perlu, dan mengorganisasi sehingga interpretasi bisa ditarik kesimpulan.

\section{b. Penyajian data}

Sekumpulan informasi tersusun yang memberi kemungkinan untuk menarik kesimpulan dan pengambilan tindakan. Bentuk penyajiannya

\footnotetext{
${ }^{11}$ Ibid, h. 158.

${ }^{12}$ Lexy J.Moleong, Metodologi...,h. 248.

Al-Madrasah: Jurnal Ilmiah Pendidikan Madrasah Ibtidaiyah

Vol. 3, No. 2, Januari-Juni 2019 
Miftahul Jannah: Peranan Guru dalam Pembinaan Akhlak Mulia Peserta Didik (Studi Kasus di MIS Darul Ulum, Madin Sulamul Ulum dan TPA Az-Zahra Desa Papuyuan)

antara lain berupa teks naratif, matriks, grafik, jaringan, dan bagan. Tujuannya dalah untuk memudahkan membaca dan menarik kesimpulan. Dengan menyajikan data maka akan memudahkan untuk memahami apa yang terjadi, merencanakan kerja selanjutnya berdasarkan apa yang telah difahami tersebut.

\section{c. Penarikan kesimpulan (verifikasi)}

Dasar penarikan kesimpulan adalah dari berbagai hasil analisis melalui catatan dilapangan, baik dari hasil wawancara, pengamatan maupun dokumen. Setelah data dianalisis secara terus menerus baik waktu pengumpulan data dilapangan dalam proses maupun sesudah dilapangan kemudian ditarik kesimpulan dan melakukan proposisi penelitian. Verifikasi (penarikan) kesimpulan dilakukan selama penelitian berlangsung sampai sesudah penelitian dan pelaporan hasil penelitian. ${ }^{13}$

\section{Pengecekan Keabsahan Data}

Pengecekan keabsahan data, peneliti menggunakan teknik trianggulasi. ${ }^{14}$ Teknik trianggulasi yang digunakan penulis adalah sebagai berikut:

a. Triangulasi pengumpulan data, dilakukan dengan membandingkan data yang dilakukan dengan mengumpulkan melalui wawancara dengan data yang diperoleh melalui observasi atau informasi yang diperoleh melalui studi dokumentasi.

b. Triangulasi teori, menurut Lincoln dan Guba berdasarkan anggapan bahwa fakta tidak bisa diperiksa derajat kepercayaannya dengan satu atau lebih teori.

c. Triangulasi dengan sumber, yaitu dengan membandingkan dan mengecek balik derajat kepercayaan suatu informasi yang diperoleh melalui tehnik pengumpulan data yang berbeda.

\footnotetext{
${ }^{13}$ Basrowi dan Suwandi, Memahami..., h. 209-210.

${ }^{14}$ Lexy J. Moleong, Metodologi..., h. 330.
} 
Miftahul Jannah: Peranan Guru dalam Pembinaan Akhlak Mulia Peserta Didik (Studi Kasus di MIS Darul Ulum, Madin Sulamul Ulum dan TPA Az-Zahra Desa Papuyuan)

d. Triangulasi metode, yaitu dilakukan dengan cara memanfaatkan penggunaan beberapa metode yang berbeda untuk mengecek kembali derajat kepercayaan informasi yang diperoleh.

\section{Pembahasan}

\section{Pengertian Akhlak}

a. Secara Etimologis

Secara etimologis kata “akhlak” berasal dari bahasa Arab (الَْخْنَاُقُ)

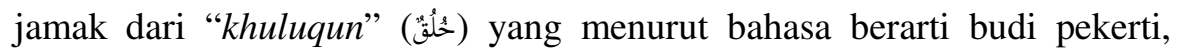
perangai, tingkah laku atau tabiat. Kata tersebut mengandung segi-segi persesuaian dengan perkataan "khalqun" (خَلْقُ) yang berarti kejadian, yang juga erat hubungannya dengan "khâliqun" (خَالقِقُ) yang berarti pencipta demikian pula dengan "makhlûqun" (عَنْؤُقُ) yang berarti yang diciptakan. Perumusan pengertian akhlak timbul sebagai media yang memungkinkan adanya hubungan baik antara khâliq dengan "makhlûq". ${ }^{15}$ Dari pengertian etimologis seperti ini, akhlak bukan saja merupakan tata aturan atau norma perilaku yang mengatur hubungan antar sesama manusia, tetapi juga norma yang mengatur hubungan antara manusia dengan Tuhan dan bahkan dengan alam semesta sekalipun. ${ }^{16}$

b. Secara Terminologis

Secara terminologis, pengertian akhlak telah banyak dikemukakan oleh para ulama, di antaranya adalah Al-Ghazali dalam kitabnya yang termasyhur "Ihyâ 'Ulûm al-Dîn" mendefinisikan akhlak sebagai: ${ }^{17}$

\footnotetext{
${ }^{15}$ A. Mustofa, Akhlak Tasawuf (Bandung: Pustaka Setia, 2010), h.11.

${ }^{16}$ Yunahar Ilyas, Kuliah Akhlaq (Yogyakarta: LPPI, 2006), h.1.

${ }^{17}$ Al-Ghazali, Ihyâ' 'Ulûm ad-Dîn, jilid 3 (t.tp, Syirkah al-Nur Asia, t.th), h.52. 
Miftahul Jannah: Peranan Guru dalam Pembinaan Akhlak Mulia Peserta Didik (Studi Kasus di MIS Darul Ulum, Madin Sulamul Ulum dan TPA Az-Zahra Desa Papuyuan)

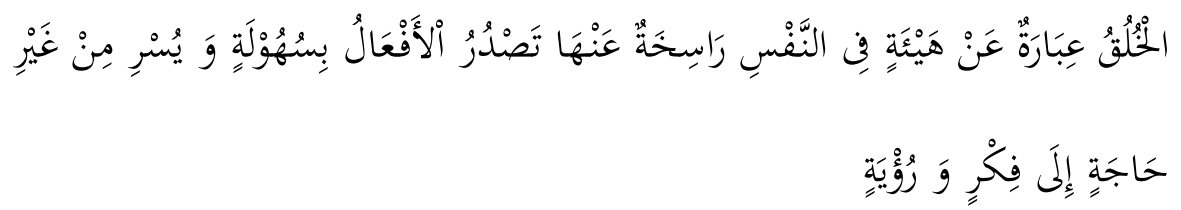

Berdasarkan pengertian ini maka yang dimaksud dengan akhlak adalah perbuatan yang membiasa pada diri seseorang. Ia merupakan refleksi dari perbuatan batinnya dan biasa dilakukan secara berulang-ulang sehingga perbuatannya tanpa memerlukan berbagai pertimbangan akalnya terlebih dahulu. ${ }^{18}$

Prof. Dr. Ahmad Amin memberikan definisi bahwa akhlak merupakan: ${ }^{19}$

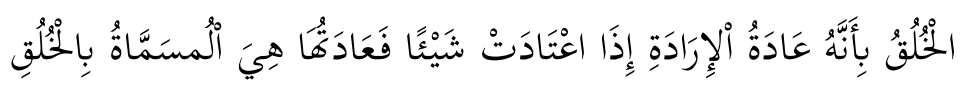

Menyimak pengertian ini, maka yang dimaksud dengan akhlak adalah 'âdatu al-irâdah atau kehendak yang dibiasakan. Dengan kehendak itulah manusia melakukan suatu perbuatan, baik perbuatan batin maupun perbuatan lahir. Dan suatu perbuatan yang dibiasakan itulah yang dinamakan akhlak. ${ }^{20}$

Berikutnya definisi akhlak yang dikemukakan oleh Ibn Maskawaih, menurutnya akhlak merupakan: ${ }^{21}$

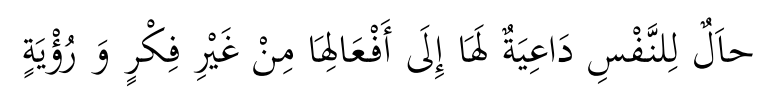

Apabila Prof. Dr. Ahmad Amin menggunakan istilah irâdah (kehendak), maka Ibn Maskawaih menggunakan hâlu al-nafsi (keadaan jiwa). Di sini dapat diambil garis kesamaan bahwa perbuatan batiniahlah yang mendorong seseorang untuk melakukan perbuatan lahiriah. Meskipun

\footnotetext{
${ }^{18}$ M. Nipan Abdul Halim, Menghias Diri Dengan Akhlak Terpuji (Yogyakarta: Mitra Pustaka, 2000), h. 12.

${ }^{19}$ Ahmad Amin, Etika ilmu akhlak (Jakarta: Bulan Bintang, 1995), h. 62.

${ }^{20}$ M. Nipan Abdul Halim, Menghias Diri...,h. 10.

${ }^{21}$ Ibnu Miskawaih, Menuju Kesempurnaan Akhlak, diterjemahkan oleh Helmi Hidayat (Bandung: Mizan, 1994), h. 56.
} 
Miftahul Jannah: Peranan Guru dalam Pembinaan Akhlak Mulia Peserta Didik (Studi Kasus di MIS Darul Ulum, Madin Sulamul Ulum dan TPA Az-Zahra Desa Papuyuan)

pada hakikatnya kedua perbuatan itu merupakan satu kesatuan perbuatan. Karena perbuatan lahiriah hanyalah merupakan refleksi dari perbuatan batiniah. ${ }^{22}$ Dan ketika perbuatan ini sudah menjadi kebiasaan dan dilakukan berulang-ulang tanpa memerlukan pemikiran maka yang demikian dinamakan akhlak.

Dari ketiga definisi akhlak yang telah dikemukakan para ulama di atas, dapat disimpulkan bahwa akhlak adalah sifat yang tertanam dalam jiwa, dilakukan berulang-ulang dan muncul secara spontan tanpa memerlukan berbagai pemikiran dan perenungan terlebih dahulu. Akhlak bersifat kejiwaan dan abstrak yang bentuk konkritnya termanifestasikan dalam perbuatan-perbuatan (berupa tindakan atau perilaku). Jika sifat yang tertanam itu darinya terlahir perbuatan-perbuatan baik dan terpuji, maka sifat tersebut dinamakan akhlak yang baik atau terpuji, sebaliknya jika sifat yang tertanam itu darinya terlahir perbuatan-perbuatan jahat dan tercela maka sifat tersebut dinamakan akhlak tercela, dan hal ini sangat tergantung dari cara pembentukan dan pembinaannya

Di samping istilah akhlak, juga dikenal istilah etika dan moral. Ketiga istilah itu sama-sama menentukan nilai baik dan buruk sikap dan perbuatan manusia. Perbedaannya terletak pada standar masing-masing. Bagi akhlak standarnya adalah Alquran dan Sunnah, bagi etika standarnya pertimbangan akal pikiran, dan bagi moral standarnya adat kebiasaan yang umum berlaku di masyarakat. ${ }^{23}$

\section{Sumber Akhlak}

Sumber akhlak adalah yang menjadi ukuran baik dan buruk atau mulia dan tercela. Sebagaimana keseluruhan ajaran Islam, sumber akhlak adalah Alquran dan Sunnah, bukan akal pikiran atau pandangan masyarakat sebagaimana konsep etika dan moral. Dalam konsep akhlak, segala sesuatu itu dinilai baik atau buruk, terpuji atau tercela, semata-mata karena syara' (Alquran

\footnotetext{
${ }^{22}$ M. Nipan Abdul Halim, Menghias Diri...,h. 11.

${ }^{23}$ Yunahar Ilyas, Kuliah...,h. 3.
} 
Miftahul Jannah: Peranan Guru dalam Pembinaan Akhlak Mulia Peserta Didik (Studi Kasus di MIS Darul Ulum, Madin Sulamul Ulum dan TPA Az-Zahra Desa Papuyuan)

dan Sunnah) menilainya demikian. ${ }^{24}$ Ukuran baik dan buruknya tidak hanya dipandang dari sudut kemanusiaan, tetapi juga dipandang dari sudut ketuhanan. Karena akhlak bersumber dari syara' maka kalaupun suatu perbuatan tidak berhubungan langsung dengan orang lain ataupun perbuatan tersebut tidak ada yang mengetahuinya, maka pahala dan dosa tetap berlaku, karena bagi syara' Tuhan selalu mengawasi setiap perbuatan manusia, sehingga manusia lebih berhati-hati dalam berbuat karena merasa diawasi oleh Tuhannya. Berbeda dengan konsep etika dan moral yang bersumber dari akal pikiran, pandangan dan adat yang berlaku di masyarakat, ganjaran dan sanksi hanya akan berlaku jika ada orang lain yang mengetahuinya.

Islam tidak mengakui bahwa norma akhlak manusia itu ditentukan oleh budaya masyarakat dan lingkungan. Sebab apabila demikian, dalam masyarakat yang banyak anggotanya melakukan penyimpangan, maka akan menjadikan perbuatan menyimpang sebagai norma masyarakat, dan akhirnya akan menjadikan orang yang paling sering menyimpang sebagai orang yang berakhlak.

Islam mengajarkan bahwa norma akhlak seseorang ditentukan oleh hidâyah (petunjuk) Allah, dalam bentuk ayat-ayat Alquran dan pelaksanaan atau penerapannya dilakukan oleh Rasulullah SAW dengan sikap uswatun hasanah kepada manusia. ${ }^{25}$ Pribadi Rasulullah SAW adalah contoh yang paling tepat untuk dijadikan teladan dalam membentuk pribadi yang berakhlakul karimah. ${ }^{26}$ Hal ini dinyatakan Allah dalam firman-Nya pada Q.S. al-Ahzâb/ 33:21. yang berbunyi:

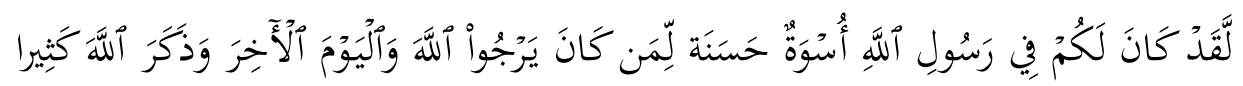

${ }^{24}$ Ibid, h. 4.

${ }^{25}$ Abdullah Salim, Akhlaq Islam: Membina Rumah Tangga dan Masyarakat (Jakarta: Media Dakwah, 1994), h. 13.

${ }^{26}$ Rosihan Anwar, Akhlak Tasawuf (Bandung: Pustaka Setia, 2010), h. 22. 
Miftahul Jannah: Peranan Guru dalam Pembinaan Akhlak Mulia Peserta Didik (Studi Kasus di MIS Darul Ulum, Madin Sulamul Ulum dan TPA Az-Zahra Desa Papuyuan)

Dalam melaksanakan berbagai kegiatan pembinaan akhlak mulia siswa di sekolah, tentu tidak terlepas dari perak aktif seorang guru. Guru merupakan sosok penentu bagi keberhasilan proses pembinaan akhlak mulia yang dilakukan di sekolah. Guru adalah orang dewasa yang secara sadar bertanggung jawab dalam mendidik, mengajar, dan membimbing peserta didik (Hamzah B. Uno, 2008: 15). Secara umum istilah guru disejajarkan dengan pendidik, ini didasarkan atas dasar tugas yang dikerjakan yaitu membimbing dan mengajarkan pengetahuan dan keterampilan kepada siswa.

Kata pendidik berasal dari kata dasar didik, yang artinya memelihara, merawat dan memberi latihan agar seseorang memiliki ilmu pengetahuan seperti yang diharapkan (tentang sopan santun, akal budi, akhlak, dan sebagainya) Ramayulis \& Samsul Nizar (2009: 138). Istilah pendidik dalam Islam adalah siapa saja yang bertanggung jawab terhadap perkembangan anak didik (Ahmad Tafsir, 2008: 74). Dengan demikian, makna pendidik ini lebih bersifat umum, tidak terbatas pada lingkungan formal seperti sekolah, dan tidak ada penekanan standar kualifikasi profesi yang baku.

Seorang yang disebut guru adalah orang yang memiliki kemampuan untuk merancang program pembelajaran, serta mampu menata dan mengelola kelas agar siswa dapat belajar dan pada akhirnya dapat mencapai tingkat kedewasaan sebagai tujuan akhir dari proses pendidikan. Dalam melaksanakan tugasnya, guru harus memiliki integritas dalam melakukan segala sesuatu yang akan diajarkan pada siswa tidak terbatas hanya di ruang kelas.

Integritas yang melekat pada seorang guru tentu tidak terlepas dari pengamatan keseharian siswa. Ini artinya, siswa secara tidak langsung akan mengevaluasi akhlak mulia gurunya yang didasarkan pada bagaimana cara guru memperlakukan siswa dalam proses pembelajaran. Secara tidak langsung dalam proses pembelajaran, siswa mengetahui bagaimana seorang guru dapat berperan sebagai teladan dengan mengajar karakter dan nilai-nilai moral (akhlak mulia), 
Miftahul Jannah: Peranan Guru dalam Pembinaan Akhlak Mulia Peserta Didik (Studi Kasus di MIS Darul Ulum, Madin Sulamul Ulum dan TPA Az-Zahra Desa Papuyuan)

seperti kejujuran, kepercayaan, keadilan, rasa hormat, dan tanggung jawab (Dimyati, 2010: 85)

Dalam mengupayakan terciptanya pembinaan akhlak mulia siswa oleh guru, hendaknya tetap mengacu pada prinsip yang selalu diteladankan serta diajarkan Rasulullah saw, dalam menanamkan rasa keimanan dan akhlak mulia terhadap siswa. Prinsip tersebut menurut Abdul Majid (2008: 131-132), antara lain:

a. Motivasi, ini dapat terlihat pada setiap ucapan dan perbuatan Rasulullah saw, kesemuanya itu mengandung motivasi yang kuat kepada para sahabat serta dorongan untuk berbuat kebaikan dan meninggalkan kejahatan.

b. Fokus, dalam menyampaikan pelajaran hendaknya terfokus pada permasalahan yang disampaikan, sehingga siswa tidak menjadi kebingungan.

c. Penyampaian materi tidak terlalu cepat agar siswa dapat memahami maksud dari apa yang disampaikan oleh guru.

d. Senantiasa melakukan pengulangan penyampaian materi yang dianggap perlu untuk ditekankan agar siswa lebih kuat ingatannya.

e. Analogi langsung, ini dimaksudkan agar siswa dapat mengembangkan potensi berpikirnya, sehingga timbul kesadaran dan tafakkur serta melakukan muhasabah (introspeksi) diri.

f. Memperhatikan keragaman siswa, ini artinya guru harus berusaha memperhatikan kondisi keberagaman siswa, dengan demikian diharapkan guru dapat melayani serta mempasilitasi kebutuhan siswa.

g. Memperhatikan tiga tujuan akhlak (kognitif, emosional, dan kinetik).

h. Memperhatikan pertumbuhan dan perkembangan siswa.

i. Menumbuhkan kreativitas siswa dengan mengajukan beberapa pertanyaan untuk mengetahui tanggapan dan pemahaman siswa terhadap apa yang sudah disampaikan. 
Miftahul Jannah: Peranan Guru dalam Pembinaan Akhlak Mulia Peserta Didik (Studi Kasus di MIS Darul Ulum, Madin Sulamul Ulum dan TPA Az-Zahra Desa Papuyuan)

j. Berbaur dengan siswa dan masyarakat serta tidak eksklusif dalam berbagai kegiatan seperti musyawarah, kerja bakti, dan lain sebagainya.

k. Do'a, hendaknya setiap kali akan memulai pelajaran diawali dengan berdo'a dan diakhiri pula dengan berdoa kepada Allah swt, dengan harapan akan tetap memperoleh ilmu yang barokah dan bermanfaat.

1. Teladan, satu kata antara ucapan dan perbuatan, ini artinya guru harus bisa merealisasikan apa yang diajarkan kepada siswa dengan langsung sebagai contoh/teladan bagi sisw dengan niat yang tulus semata-mata karena mengharap akan Rahmat serta balasan dari Allah swt.

Dalam rangka menerapkan prinsip yang diajarkan Rasulullah saw, tersebut, seorang guru dalam melaksanakan tugasnya hendaknya disertai dengan rasa cinta dan kasih sayang yang selalu muncul dalam proses pembinaan akhlak mulia siswa. Perlakuan kasih sayang dan cinta ini menurut Prayitno (2009: 124125) dapat teraktualisasikan antara lain dalam bentuk:

a. Sopan, ini didasari rasa kasih saying dimana guru dengan lembutnya menyapa siswa, memanggil dengan nama yang menarik, mengucapkan salam, dan menegur dengan manis, segar dan bersemangat.

b. Respon positif, ini didasari rasa kasih sayang dengan lembutnya memberikan respon melalui cara-cara yang sopan, kata-kata yang baik, menghindari penggunaan kata yang menghina, melecehkan, merendahkan, kasar ataupun tidak pantas.

c. Penampilan simpati dan empati, ini merupakan wujud dari kasih sayang guru yang ditampilkan melalui tingkah laku kelembutan dengan ucapan, tulisan, sentuhan, serta ungkapan-ungkapan lain dalam bentuk tanda ataupun simbol-simbol tertentu.

d. Tutur kata, intonasi, tekanan suara dan irama yang wajar, dengan kata atau kalimat yang mengenakkan, dengan sikap dan tingkah pola yang sopan, dan menghargai orang lain. 
Miftahul Jannah: Peranan Guru dalam Pembinaan Akhlak Mulia Peserta Didik (Studi Kasus di MIS Darul Ulum, Madin Sulamul Ulum dan TPA Az-Zahra Desa Papuyuan)

e. Ajakan dan dorongan, mengajak dan mendorong secara tulus dan ikhlas, mengajak sebagai mitra bukan penguasa, mengutamakan persuasi dari pada intruksi, dan bersikap akomodatif dari pada konfrontatif.

Terkait dengan prinsip-prinsip yang harus diperhatikan oleh guru dalam pembinaan akhlak mulia, Lickona (Mindes, 2006: 32-33) mengemukakan lima prinsip yang harus dipertimbangkan guru dalam pembinaan akhlak mulia siswa yaitu:

a. Relationships matter, so plan to relate individually to each child and to promote relationships among and between children.

b. Bond through social convention such as "handshake," so use the conventions of social pleasantries to promote and receive respect.

c. Know students as individuals with personalities, cultural perspectives, and cognitive approaches.

d. Positive relationships with teacher influence child behavior, so think about it when you start with the negative in interactions with children.

e. Teach by example with respect for students, as shown by personal interest in the stories they tell and the stresses they bring.

Dari kelima prinsip yang dikemukakan Lickona tersebut, dapat diketahui bahwa guru dalam melakukan pembinaan akhlak mulia siswa harus mempertimbangkan banyak hal. Ini antara lain menyangkut bagaimana guru menjalin hubungan baik dengan siswa, memperaktikkan atau mencontohkan kepada siswa tindakan akhlak mulia dalam kehidupan sehari-hari seperti berjabat tangan sebagai bentuk penghormatan kepada siswa, guru juga harus memahami karakteristik individu siswa yang meliputi kognitif, afektif dan prikomotorik, serta tetap berusaha mempengaruhi perilaku siswa kearah yang positif.

Dari penjelasan pendapat para ahli di atas, dapat diketahui bahwa tugas seorang guru cukup kompleks. Guru dituntut mampu mempersiapkan siswa menjadi manusia yang manusiawi yang meliputi hubungan manusia dengan 
Miftahul Jannah: Peranan Guru dalam Pembinaan Akhlak Mulia Peserta Didik (Studi Kasus di MIS Darul Ulum, Madin Sulamul Ulum dan TPA Az-Zahra Desa Papuyuan)

Tuhan, hubungan manusia dengan manusia lainnya sebagai makhluk sosial, dan hubungan manusia dengan lingkungan sekitar. Guru juga harus memperhatikan kebutuhan akan pengembangan aspek kesehatan jasmani, sehingga dapat tercipta akhlak mulia siswa, yang seimbang antara kebutuhan dunia dan akhirat, sesuai dengan Firman Allah swt. (QS. Al-Qashash: 77) yang artinya: Dan carilah pada apa yang telah dianugerahkan Allah kepadamu (kebahagiaan) negeri akhirat, dan janganlah kamu melupakan bahagianmu dari (kenikmatan) duniawi dan berbuat baiklah (kepada orang lain) sebagaimana Allah telah berbuat baik, kepadamu, dan janganlah kamu berbuat kerusakan di (muka) bumi. Sesungguhnya Allah tidak menyukai orang-orang yang berbuat kerusakan (Departemen Agama RI, 2005: 395).

\section{Peran Guru dalam Membina Akhlaq}

Perhatian Guru dalam mendidik dan membina kehidupan beragama di sekolah memberikan pengaruh positif dalam pembentukan akhlak remaja, Guru Islam memiliki peranan penting dalam pembentukan akhlak remaja, karena Guru adalah sebagai sosok insan yang berwibawa dan dihormati oleh anak. Pentingnya bimbingan agama di sekolah, dikemukakan Sudarsono bahwa: "Didikan agama yang diterima oleh anak sangat mempengaruhi sikap dan perilakunya karena akan menjadi landasan dalam berbuat dan bertindak dalam pergaulannya, terlebih lagi jika ditambah dengan pengawasan dan pembinaan dari guru secara teratur dan kontinyu", 27

Selain bimbingan agama di sekolah juga diperlukan proses belajar agama di luar rumah tangga atau di lingkungan masyarakat melalui didikan agama Islam secara non formal agar anak-anak bergaul dengan orang-orang di masyarakat yang mengandung sifat positif dalam bidang keagamaan. Sebab bila tidak diarahkan akan mengakibatkan pengaruh buruk bagi anak. Zuhairini menjelaskan bahwa "pengaruh teman sebaya sangat kuat dan sangat cepat kepada akal dan akhlak anak-anak sehingga masa depan anak sangat tergantung

${ }^{27}$ Zakiah Daradjat, Pembinaan Remaja, Bulan Bintang, Jakarta, 1976, h . 43. 
Miftahul Jannah: Peranan Guru dalam Pembinaan Akhlak Mulia Peserta Didik (Studi Kasus di MIS Darul Ulum, Madin Sulamul Ulum dan TPA Az-Zahra Desa Papuyuan)

dari pengaruh yang timbul dari lingkungan teman sebaya". ${ }^{28}$ Dari pendapat di atas, bahwa pengarahan kepada anak perlu diberikan oleh Guru agar mereka aktif belajar agama terutama di luar lingkungan sekolah serta tidak berbuat buruk. Zakiah Daradjat menyatakan : Guru hendaknya membimbing anaknya ke arah hidup sesuai dengan ajaran agama, sehingga anak akan terbiasa hidup sesuai dengan nilai-nilai akhlak yang diajarkan agama, kebiasaan yang tertanam sejak kecil itu merupakan bibit dari unsur-unsur kepribadian yang akan bertumbuh dan akan menjadi pengendali akhlaknya dikemudian hari. ${ }^{29}$ Dengan bimbingan agama oleh guru di sekolah, memberikan pengaruh positif bagi perkembangan hidup remaja sampai dewasa nanti dimana dengan pembentukan sejak kecil, dapat dijadikan sebagai modal bagi pertumbuhan dan perkembangan kepribadiannya.

Bimbingan agama Islam seperti ibadah shalat, dengan cara melatih dan membiasakan para remaja dalam kehidupan sehari-hari dapat mewujudkan dua tujuan penting, antara lain membiasakan remaja dalam melakukan ibadah shalat, akan menjadikannya seseorang yang sopan dan santun dalam menunaikan kewajibanya, terbiasa disiplin dan mengatur waktu sejak kecil, dan melemahkan pengaruh serta kekuasaan syetan yang selalu membayangbayanginya. Menumbuhkan rasa taat anak pada gurunya. Ketaatannya kepada guru biasanya berkaitan erat dengan ketekunannya dalam menunaikan ibadah shalat itu, merupakan tanda dan latihan diri dalam melakukan ketaatan. Maka dengan pengarahan dan pembinaan yang instensip dalam masalah shalat ini akan memudahkan memperoleh ketaatan dalam berbagai aspek kehidupan.

Bimbingan agama khususnya agama Islam oleh guru di sekolah dapat membentuk akhlak yang baik bagi anak-anaknya baik pada saat kecil maupun ia dewasa kelak. Tanpa adanya bimbingan agama maka dapat berakibat negatif bagi akhlak anak. Jadi bimbingan agama dalam lingkungan sekolah yang

\footnotetext{
${ }^{28}$ Zuhairini, dkk.,, Metodik Khusus Pendidikan Agama Islam, Usaha Nasional, Surabaya, 1981, h . 33.

${ }^{29}$ Zakiah Daradjat, Pembinaan Remaja, Bulan Bintang, Jakarta, 1976, h . 47. 
Miftahul Jannah: Peranan Guru dalam Pembinaan Akhlak Mulia Peserta Didik (Studi Kasus di MIS Darul Ulum, Madin Sulamul Ulum dan TPA Az-Zahra Desa Papuyuan)

dilaksanakan oleh guru dalam membentuk akhlak anak-anaknya dimana lalainya guru dalam membimbing anak dapat mengakibatkan kerusakan akhlak pada diri anak bahkan berarti guru Islam telah menjerumuskan anak kepada kesesatan.

Namun terkadang usaha yang dilakukan oleh guru kurang membuahkan hasil disebabkan berbagai faktor seperti kondisi lingkungan sosial ekonomi yang kurang baik, tempat pendidikan anak tidak agamis, teman bergaul tidak baik akhlaknya dan sebagainya. Oleh sebab itu Zuhairini, dkk., menyatakan "masa depan anak sangat tergantung kepada teman bergaulnya". ${ }^{30}$ Dengan demikian selain mengusahakan pembinaan dan pendidikan akhlak remaja juga harus diperhatikan kondisi lingkungan bergaul anak agar dapat berhasil dengan baik.

Pembinaan akhlaq karimah kepada peserta didik harus diberikan secara kontinu agar mereka dapat meneladani akhlaq karimah yaitu akhlaq mulia yang dicontohkan oleh Rasulullah SAW serta mampu menjauhi sifat-sifat yang buruk yang harus dihindarkan oleh anak, dan guru agama Islam harus mampu membimbing akhlaq anak agar mereka dapat istiqomah dalam mempergunakan akhlaq yang baik, hal ini sesuai dengan hadits Nabi yaitu :

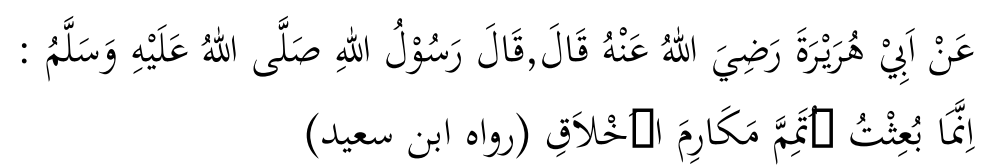

Artinya: "Dari Abu Hurairah RA. berkata: Rasulullah bersabda "Sesungguhnya aku diutus untuk menyempurnakan akhlaq akhlaq".(HR. Ibnu Said $)^{31}$

Sebagai upaya menciptakan peserta didik agar memiliki akhlaq yang baik, terlebih dahulu harus dimulai dari guru itu sendiri dengan memiliki pribadi yang baik, hal sebagaimana dikatakan oleh Zakiah Daradjat, bahwa :

\footnotetext{
${ }^{30}$ Zuhairini, dkk.,, Metodik Khusus Pendidikan Agama Islam, Usaha Nasional, Surabaya, 1981, h. 33.

${ }^{31}$ Imam as Sayuti, Jamius Shaghir, Penerjemah Syarif Sukandi, Al Maarif, Bandung, 1989, h. 56.
} 
Miftahul Jannah: Peranan Guru dalam Pembinaan Akhlak Mulia Peserta Didik (Studi Kasus di MIS Darul Ulum, Madin Sulamul Ulum dan TPA Az-Zahra Desa Papuyuan)

"Tingkah laku atau moral guru pada umumnya merupakan penampilan lain dari kepribadiannya. Bagi anak didik guru adalah contoh tauladan yang sangat penting dalam pertumbuhannya, guru adalah orang yang pertama sesudah orang tua,yang mempengaruhi pembinaan kepribadian anak didik kalaulah tingkah laku atau akhlak guru tidak baik, pada umumnya akhlak anak didik akan rusak olehnya, karena anak akan mudah terpengaruh oleh orang yang dikaguminya". ${ }^{32}$

Berdasarkan kutipan di atas dapat dipahami bahwa peserta didik di sekolah akan memiliki akhlaq yang baik apabila terlebih dahulu guru agama yang mendidik mereka dapat memberikan contoh yang baik, sebab guru adalah orang pertama sesudah orang tua yang dapat mempengaruhi kepribadian anak didik. Jadi jelas, jika tingkah laku atau kepribadian guru tidak baik maka anak didiknya juga akan kurang baik karana kepribadian seorang anak mudah sekali terpengaruh oleh orang yang dikaguminya.

Eksistensi guru sangat menentukan dalam membina akhlaq peserta didik, karena disamping guru berperan sebagai pengajar, guru juga berperan sebagai pengarah yang mempunyai tanggung jawab untuk melihat segala sesuatu yang terjadi pada diri siswa di sekolah. Dengan demikian para guru hendaknya memahami prinsip-prinsip bimbingan dan menerapkan dalam proses belajar mengajar, dan seorang guru hendaknya selalu memberikan pengarahan atau mengarahkan anak didiknya kepada hal-hal yang sesuai dengan ajaran agama Islam.

Pembinaan akhlaq pada dasarnya menuntut seseorang agar memberi petunjuk agar peserta didik dapat berbuat baik dan meninggalkan yang tidak baik, maka sangat penting diadakannya pembinaan akhlak, karena seseorang yang memiliki pengetahuan dalam hal ilmu akhlak biasanya lebih baik perilakunya dari pada orang yang tidak mempunyai pengetahuan ilmu akhlak tersebut. Pada fase perkembangan anak didik menuju kearah kedewasaannya, anak sering mengalami kegoncangan dan keraguan yang penuh dengan ketidak

${ }^{32}$ Zakiah Daradjat, Kepribadian Guru, Bulan Bintang, Jakarta, 1982, h . 18. 
Miftahul Jannah: Peranan Guru dalam Pembinaan Akhlak Mulia Peserta Didik (Studi Kasus di MIS Darul Ulum, Madin Sulamul Ulum dan TPA Az-Zahra Desa Papuyuan)

seimbangan, emosi, kecemasan dan kekhawatiran. Dalam keadaan yang demikian anak didik perlu ditanamkan kepercayaan kepada Allah, sifat-sifat Allah, arti dan manfaat agama, cinta kepada Allah dan Rasul-Nya, sifat-sifat yang terpuji seperti pemaaf, sabar dan menepati janji. Dalam hal akhlak maka umat Islam wajib meneladani Rasulullah SAW sebagaimana firman Allah SWT yaitu :

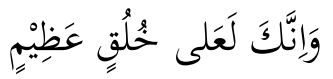

Artinya :"Dan sesungguhnya kamu benar-benar berbudi pekerti yang agung”.(QS. Al Qalam : 4) ${ }^{33}$

Untuk membina peserta didik agar menjadi manusia yang memiliki akhlaq sebagai seorang muslim, maka guru Aqidah Akhlaq melaksanakan berbagai upaya secara sistemik, kontinyu dan berkesinambungan seperti :

1. Menanamkan nilai-nilai agama sejak dini, sehingga nantinya akan membentuk sikap dan kepribadian peserta didik sejak dini.

2. Memberikan suri teladan/contoh perbuatan baik dalam kehidupan sehari-hari.

3. Mengadakan kegiatan keagamaan seperti perayaan hari besar Islam.

4. Mengadakan pembinaan keagamaan seperti tatacara shalat, wudhu, tayamum, berdoa, berzikir, shalat jamaah dan lain-lain.

5. Memberi teguran secara lisan dan tulisan kepada peserta didik apabila ada yang berbuat yang mencerminkan akhlaq yang buruk.

6. Memberikan arahan dan motivasi tentang pentingnya melakukan berbagai kewajiban seorang hamba kepada Allah seperti puasa, zakat, berdoa, shalat dalam kehidupan sehari-hari. ${ }^{34}$

Indikator dari keberhasilan seorang guru dalam membina akhlaq peserta didiknya yaitu :

\footnotetext{
${ }^{33}$ Zakiah Daradjat, Kepribadian Guru..., h. 18.

${ }^{34}$ Sulaiman, Menjadi Guru, Diponegoro, Bandung, 2005, h . 26. 
Miftahul Jannah: Peranan Guru dalam Pembinaan Akhlak Mulia Peserta Didik (Studi Kasus di MIS Darul Ulum, Madin Sulamul Ulum dan TPA Az-Zahra Desa Papuyuan)

a. Peserta didik bersemangat dalam beribadah kepada Allah seperti shalat, puasa, berzikir, berdo'a dan lain-lain.

b. Peserta didik mampu membaca Alquran dan menulisnya dengan benar serta berusaha memahaminya.

c. Peserta didik terbiasa berkepribadian muslim (berakhlaq mulia)

d. Peserta didik mampu memahami tarikh Islam pada masa Khulafaul Rasyidin

e. Peserta didik menerapkan ajaran Islam dalam kehidupan sehari-hari. ${ }^{35}$ Untuk membentuk peserta didik agar menjadi manusia yang memiliki akhlaqul karimah, yang taat kepada Allah dan menyerahkan diri sepenuhnya kepada-Nya, maka guru Aqidah Akhlaq harus menjalankan peranannya dalam membina akhlaq secara sistemik, kontinyu dan berkesinambungan seperti melakukan upaya-upaya di bawah ini :

1. Menanamkan nilai-nilai agama sejak dini, sehingga nantinya akan menbentuk sikap dan kepribadian peserta didik sejak dini.

2. Memberikan suri teladan atau contoh perbuatan yang baik dalam kehidupan sehari-hari.

3. Membiasakan mengadakan kegiatan keagamaan seperti perayaan hari besar Islam.

4. Mengadakan pembinaan keagamaan seperti tatacara shalat, wudhu, tayamum, berdoa, berzikir, shalat jamaah dan lain-lain.

5. Memberi teguran secara lisan dan tulisan kepada peserta didik apabila ada yang berbuat yang mencerminkan akhlaq yang buruk.

6. Memberikan arahan dan motivasi tentang pentingnya melakukan berbagai kewajiban seorang hamba kepada Allah seperti puasa, zakat, berdoa, shalat dalam kehidupan sehari-hari

\footnotetext{
${ }^{35}$ Mansyur, Petunjuk Pelaksanaan Pendidikan Agama Islam, Dirjen Pembinaan Kelembagaan Agama Islam, Jakarta, 2006, h . 2
} 
Miftahul Jannah: Peranan Guru dalam Pembinaan Akhlak Mulia Peserta Didik (Studi Kasus di MIS Darul Ulum, Madin Sulamul Ulum dan TPA Az-Zahra Desa Papuyuan)

\section{Simpulan}

Dari uraian dan data-data penulis sajikan dalam jurnal ini, maka penulis mengambil kesimpulan:

1. Keadaan akhlak siswa di Madrasah Ibtidaiyah Swasta Darul Ulum, dan Taman Pendidikan Alquran Az-Zahra pada umumnya sudah cukup baik, akan tetapi masih ada beberapa siswa yang masih mempunyai akhlak kurang baik, diantaranya : membolos, berbicara kurang sopan, tidak mengikuti upacara dan datang terlambat. Kenakalan siswa di Madrasah Ibtidaiyah Swasta Darul Ulum, dan Taman Pendidikan Alquran Az-Zahra seharusnya lebih mendapat bimbingan, perhatian dan kontrol yang ekstra dari para guru terutama guru PAI yang tugasnya tidak hanya mengajarkan pelajaran keagamaan saja akan tetapi guru sebagai contoh untuk siswa-siswanya dan harus mengajarkan hal-hal yang baik terutama mengajarkan akhlak yang baik.

2. Peran guru Madrasah Ibtidaiyah Swasta Darul Ulum, dan Taman Pendidikan A- Quran Az-Zahra sangat berperan aktif dalam pembinaan akhlak siswa baik dalam kegiatan keagamaan maupun tidak. Kegiatan pembinaan akhlak yang dilakukan guru seperti mengajari bagaimana caranya hormat kepada guru, tata cara hidup berdisiplin yang baik, ramah pada lingkungan, shalat wajib dan sunnah berjamaah, tahfiz, habsyi, dan lain sebagainya.. Selain itu dalam pendekatan terhadap anak guru menggunakan berbagai metode diantaranya adalah

a. Metode Ummi

Dalam menyampaikan informasi atau pembinaan akhlak siswa ustadz dan ustadzah salah satunya menggunakan metode ummi supaya siswa-siswa memahami adab-adab dan tatacara yang belajar Alquran yang benar sebelum belajar Alquran. 
Miftahul Jannah: Peranan Guru dalam Pembinaan Akhlak Mulia Peserta Didik (Studi Kasus di MIS Darul Ulum, Madin Sulamul Ulum dan TPA Az-Zahra Desa Papuyuan)

b. Metode pembiasaan

Selain metode ummi dalam pembinaan akhlak siswa juga digunakan metode pembiasaan, hal ini dimaksudkan supaya siswa terbiasa dalam berperilaku baik, baik dilingkungan maupun di rumah. Contoh" metode yang saya gunakan pembiasaan, mereka dibiasakan untuk merapikan duduknya terlebih dulu dan saya berkata tepuk fokus lalu para siswa mempraktikan apa yang saya perintahkan setelah itu ketika mereka sudah displin dan rapi memerintahkan berdo'a dengan berkata ad-Do'a lalu mereka memulai aturan berdo'a dengan dilanjutkan pembacaan do'a. Setelah berdo'a saya mengulang-ulang surah-surah yang sudah mereka hafal.

c. Metode tanya jawab

Setelah melakukan metode pembiasaan dalam pembinaan akhlak siswa juga digunakan metode tanya jawab, hal ini dimaksudkan supaya siswa terbiasa dalam berprilaku baik, contoh " sebelum saya memulai mengaji saya terlebih dahulu menanyakan tentang haditshadits, misalnya bacakan hadits tidak boleh makan dan minum berdiri maka mereka akan membaca hadits tersebut. Juga guna mentes hafalan mereka tentang hadits-hadits yang bersangkutan dengan pembinaan akhlak mulia yang akan diterapkan kelak baik dilingkungan maupun dirumah. Metode tanya jawab juga saya lakukan ketika tadarus siswa sudah berada pada juz enam, yaitu dengan bertanya tentang tajwid yang sudah di baca tadi.

d. Metode Hukuman

Metode ini diterapkan dengan tujuan untuk melatih siswa agar disiplin dan bertanggung jawab terhadap apa mereka perbuat. "Metode hukuman bagi yang tidak mengikuti peraturan maka akan dihukum dengan menghafal surah-surah pendek". 
Miftahul Jannah: Peranan Guru dalam Pembinaan Akhlak Mulia Peserta Didik (Studi Kasus di MIS Darul Ulum, Madin Sulamul Ulum dan TPA Az-Zahra Desa Papuyuan)

Selain metode-metode diatas yang telah disebutkan. Seorang guru terkadang diawal dan di akhir pelajaran juga bercerita tentang kisah-kisah motivasi yang berkaitan dengan adab-adab atau akhlak mulia agar para siswa terbiasa dengan akhlak mulia.

3. Faktor pendukung dan penghambat membina akhlak mulia peserta didik di MIS Darul Ulum, dan TPA Az-Zahra Desa Papuyuan, ialah sebagai berikut:

a. Faktor pendukung seperti keluarga, lingkungan masyarakat, lingkungan tempat tinggal, dan juga tata terbit sekolah.

b. Faktor penghambat seperti keterbatasan waktu, keterbatan pengawasan, perilaku siswa, pergaulan, teknologi, kesadaran diri, dan sarana prasarana yang tidak memadai.

4. Media pembinaan siswa untuk membina akhlak mulia peserta didik di MIS Darul Ulum, dan TPA Az-Zahra Desa Papuyuan ialah guru sebagai tenaga pendidik, orang tua, dan lingkungan sekolah. 
Miftahul Jannah: Peranan Guru dalam Pembinaan Akhlak Mulia Peserta Didik (Studi Kasus di MIS Darul Ulum, Madin Sulamul Ulum dan TPA Az-Zahra Desa Papuyuan)

\section{Daftar Pustaka}

Azra, Azyumardi. Pendidikan Islam : Tradisi dan Modernisasi di Tengah Tantangan Milenium III. Jakarta: Kencana Prenada Media Group, 2012.

Basrowi dan Suwandi. Memahami Penelitian Kualitatif. Jakarta: Rineka Cipta, 2008.

Bungin, Burhan. Metodologi Penelitian Kualitatif. Jakarta: RajaGrafindo Persada, 2011.

Djumransjah, HM dan Abdul Malik Karim Amrullah. Pendidikan Islam. Malang: UIN Malang Press, 2007.

Ibn Al-Asy'ats, Abu Daud Sulaiman. Sunan Abi Dawud. Jilid 4. Cairo: Dar AlHadits, 1988.

Ibn Hanbal, Ahmad Ibn Muhammad. Al-Musnad. jilid. Beirut: Maktabah AlTurats Al-Islamiy, 1994.

Majid, Abdul dan Dian Andayani. Pendidikan Karakter Perspektif Islam. Bandung: Remaja Rosdakarya, 2011.

Masyhud, M. Sulthon, dan Moh. Khusnurdilo. Manajemen Pondok Pesantren. Jakarta: Diva Pustaka, 2005.

Maunah, Binti. Perbandingan Pendidikan Islam. Yogyakarta: Teras, 2011.

Moleong, Lexy J. Metodologi Penelitian Kualitatif. Bandung: Remaja Rosdakarya, 2007.

Mujib, Abdul. Kepribadian Dalam Psikologi Islam. Jakarta: Raja Grafindo Persada, 2006.

Mulyana, Deddy. Metodologi Penelitian Kualitatif: Paradigma Baru Ilmu Komunikasi dan Ilmu Sosial Lainnya. Bandung: Remaja Rosdakarya, 2006.

Nata, Abuddin. Pemikiran Para Tokoh Pendidikan Islam. Jakarta: Raja Grafindo Persada, 2003.

Rahmaniyah, Istighfarotur. Pendidikan Etika : Konsep Jiwa dan Etika Perspektif Ibnu Miskawaih Dalam Kontribusinya di Bidang Pendidikan. Malang: UIN Maliki Press, 2010.

Ramayulis dan Samsul Nizar. Ensiklopedi Tokoh Pendidikan Islam, Mengenal Tokoh Pendiikan di Dunia Islam dan Indonesia. Ciputat: PT. Ciputat Press Group, 2005. 
Miftahul Jannah: Peranan Guru dalam Pembinaan Akhlak Mulia Peserta Didik (Studi Kasus di MIS Darul Ulum, Madin Sulamul Ulum dan TPA Az-Zahra Desa Papuyuan)

Setiawan, Agus. Prinsip Pendidikan Karakter dalam Islam (Studi Komparasi Pemikiran al-Ghazali dan Burhanuddin al-Zarnuji), Dinamika Ilmu, 14 (1), 2014

Syahidin. Menelusuri Metode Pendidikan dalam Al-Qur'an. Bandung: CV. Alfabeta, 2009.

Undang-Undang Sistem Pendidikan Nasional No.20 Tahun 2003.

Zuhairini dkk. Filsafat Pendidikan Islam. Jakarta: Bumi Aksara, 2008. 